\title{
Autologous intrauterine transfusion in a case of anti-U
}

\author{
Sumaiya Adam* and Hennie Lombaard \\ Department of Obstetrics and Gynaecology, University of Pretoria, Pretoria, South Africa.
}

*Correspondence to: Sumaiya Adam, Department of Obstetrics and Gynaecology, Steve Biko Academic Hospital, Steve Biko Road, Pretoria, 0001, South Africa; e-mail: sumaiya.adam@up.ac.za.

\begin{abstract}
BACKGROUND: Minor red blood cell antibodies are becoming a more common cause of hemolytic disease of the newborn. Anti- $U$ are a rare alloantibody found almost exclusively in people of black descent. There is limited experience to guide the management of pregnancies complicated by anti-U. Furthermore, there is often no suitable cross-matched blood available for transfusion of a patient with anti-U.
\end{abstract}

CASE REPORT: A 21-year-old P0G1 presented at 25 weeks' gestation with D- disease in pregnancy. She had a significant indirect antiglobulin test titer of 512. Anti-U were identified and no suitable cross-matched blood was available. Maternal blood was prepared for autologous intrauterine fetal transfusion. Two such transfusions were performed.

RESULTS: A healthy fetus delivered at 32 weeks that did not require phototherapy or an exchange transfusion.

CONCLUSION: Autologous transfusion of prepared maternal blood provides a safe option for intrauterine fetal therapy in pregnancies complicated by rare alloantibodies.

\section{ABBREVIATION}

MCA-PSV - middle cerebral artery peak systolic velocity

Hemolytic disease of the newborn (HDN) was a significant cause of fetal morbidity and mortality until the introduction of amniocentesis, intrauterine transfusion, controlled early delivery, and exchange transfusion in the management of severe alloimmunized women and their fetuses. The universal use of RhIG has reduced the prevalence of HDN, but has brought the minor red blood cell (RBC) antibodies to the fore.

A 21-year-old P0G1 was referred to the fetal unit for evaluation at 25 weeks' gestation. She was blood group $\mathrm{O}, \mathrm{D}-$, indirect antiglobulin test (IAT) reaction positive with a significant titer of 512. This was her first pregnancy and she had had no prior blood transfusions. Thus far the pregnancy was uncomplicated. 
On fetal assessment she was 25 weeks 4 days pregnant with an estimated fetal weight of $774 \mathrm{~g}$. The fetus was appropriately grown for gestation with normal amniotic fluid index and umbilical artery Doppler. The fetus appeared structurally normal and there was no evidence of hydrops fetalis. The middle cerebral artery peak systolic velocity (MCA-PSV) was normal.

One week later (26 weeks 4 days) the MCA-PSV V-Max $(56.6 \mathrm{~cm} / \mathrm{sec}$ ) was greater than 1.5 multiples of median, indicating a fetal anemia. The patient was counseled and an intrauterine transfusion was planned. At the time of the transfusion, the blood services (SANBS) informed us that the patient had anti-U, from the MNS antigen system, as determined by an 11-reagent panel. At that time no suitable blood was available for the transfusion. The procedure was abandoned and corticosteroids were administered for fetal lung maturity.

After consultation with a hematologist and further discussion with the patient, the option of autologous transfusion of maternal blood was considered. The patient's hemoglobin $(\mathrm{Hb})$ level was $11.7 \mathrm{~g} / \mathrm{dL}$. The patient donated $85 \mathrm{~mL}$ of blood which was then leukoreduced, irradiated, and tightly packed to a hematocrit (Hct) of $75 \%$. We obtained $25 \mathrm{~mL}$ of blood, which was transfused uneventfully into the umbilical vein, at 28 weeks' gestation. The fetal $\mathrm{Hb}$ level was $8.7 \mathrm{~g} / \mathrm{dL}$ before transfusion. The fetal direct antiglobulin test (DAT) reaction was positive. We were unable to determine the antibody status as we had a limited fetal blood sample. The patient received $600 \mathrm{mg}$ of intravenous iron (Venofer) in three divided doses over the course of a week.

At follow-up 1 week later the MCA-PSV V-Max $(56 \mathrm{~cm} / \mathrm{sec})$ was again elevated. The mother donated an additional $100 \mathrm{~mL}$ of blood, which was prepared. Her $\mathrm{Hb}$ level at this time was $11.1 \mathrm{~g} / \mathrm{dL}$. A second intrauterine fetal transfusion of $38 \mathrm{~mL}$ of prepared maternal blood was carried out uneventfully at 30 weeks 3 days' gestation. The fetal $\mathrm{Hb}$ level was $10.8 \mathrm{~g} / \mathrm{dL}$ before transfusion. We did not retest the DAT as we were unable to obtain adequate amount of fetal blood at this procedure. At this time the fetus was appropriately grown with an estimated fetal weight of $1565 \mathrm{~g}$, with a normal amniotic fluid index and umbilical artery Doppler. There was no evidence of hydrops fetalis.

At the 32-week follow-up visit the fetus weight was $1770 \mathrm{~g}$, which was appropriate. However, the umbilical artery Doppler was raised $(0.84)$ and the amniotic fluid index was $19.8 \mathrm{~cm}$. The MCA-PSV Vmax was also increased $(56.6 \mathrm{~cm} / \mathrm{sec})$, although less reliable after two intrauterine fetal transfusions. The neonatologist was consulted and it was decided to rather deliver the fetus than repeat an autologous transfusion. A healthy $1.8-\mathrm{kg}$ neonate with an Apgar score of 7 of 10 and 9 of 10 at 1 and 5 minutes, respectively, was delivered via Cesarean section. The maternal $\mathrm{Hb}$ level was $11 \mathrm{~g} / \mathrm{dL}$. The neonatal $\mathrm{Hb}$ level was $13 \mathrm{~g} / \mathrm{dL}$ and he did not require phototherapy or exchange transfusion. The neonate was blood group 0 , $\mathrm{D}+, \mathrm{U}+$. The neonatal DAT was weakly positive but the IAT reaction was positive, indicating maternal antibodies. Anti-U were identified in neonatal blood as determined by an 11reagent panel. We thus postulated that the anemia was due to anti-U. We have no further follow-up information on the child as the family moved away from the area. 


\section{DISCUSSION}

Development of hemolytic disease of the newborn requires maternal exposure to an RBC antigen not expressed on maternal RBCs and the generation of an alloantibody. Sources of exposure include previous blood transfusion to the mother, fetomaternal bleeding, or shared needles. The likelihood of alloimmunization increases with greater volumes of allogeneic blood to which the woman is exposed. Exposure to as little as $0.5 \mathrm{~mL}$ of allogeneic blood can cause sensitization.[1]

Sensitization to minor RBC antigens may be more likely as routine testing of donor blood for antigens other than $A B O$ and $D$ is not performed. After maternal sensitization to an RBC antigen through any of the above mechanisms, subsequent exposure during a future pregnancy will elicit an antibody response of variable intensity and timing. To cause hemolysis of fetal cells, the maternal alloantibody must be transported across the placenta; thus antibodies of the IgG class are usually implicated.[1]

Minor RBC antibodies are immunoglobulins associated with RBC antigens other than $\mathrm{ABO}$ and $D$. They usually develop in response to exposure to foreign RBC antigens, but may occur naturally from exposure to bacteria or viruses. Minor antibodies associated with HDN are the Kell group, Duffy, MNS system, and P system. The MNS system contains the $M, N, S, s$, and $U$ antigens, as well as 32 other rare antigens. Naturally occurring antibodies to $\mathrm{M}$ and $\mathrm{N}$ are seen in a small percentage of the general population in the absence of exposure to allogeneic blood. Mild to severe anemia has been associated with anti-U. Smith and colleagues[2] recommended that an anti-U titer of 128 or greater or gestational age greater than 17 weeks is an indication for assessment of hemolysis in the fetus. Less than $1 \%$ of the black population is $U-$-.[3] However, anti-U, a rare cell alloantibody occurs exclusively in people of black descent.[2] All except one case report in the literature occurred in black patients (see Table 1).

There is limited experience on which to base management of pregnancies complicated by minor RBC antibodies. The American College of Obstetrics and Gynecology[7] advises that care of these women should be the same as that of women with Rh alloimmunization. Doppler assessment of the fetal MCA-PSV is the best method for monitoring fetuses at high risk of anemia. [8] This is based on the premise that the anemic fetus preserves oxygen delivery to the brain by increasing cerebral flow of low viscosity blood. The sensitivity of increased MCA-PSV above 1.5 multiples of median has approximately $100 \%$ sensitivity in the prediction of moderate to severe anemia.

The infusion of RBCs into the fetus is one of the most successful in utero therapies. It is indicated to prevent fetal death due to severe anemia and is performed between 18 and 35 weeks' gestation. Usually group O D- blood is transfused. Donor units are screened for cytomegalovirus, gamma irradiated to prevent graft-versus-host reaction, leukoreduced, washed, and tightly packed to a Hct level of $75 \%$ to $85 \%$.

Autologous donation by pregnant women can be considered, especially when rare antibodies are present. The advantage of this is that this eliminates the mother's risk of becoming sensitized to donor RBC antigens. However, the mother should ideally have a $\mathrm{Hb}$ 


\begin{tabular}{|c|c|c|}
\hline Country & Pregnancy details & Pregnancy outcome \\
\hline $\begin{array}{l}\text { Brazil }^{3} \text { (nonblack } \\
\text { patient) }\end{array}$ & $\begin{array}{l}\text { P3G4 } \\
\text { No prenatal data }\end{array}$ & $\begin{array}{l}\text { Neonate born at } 38 \text { weeks with good Apgar score } \\
\text { Neonate had anti-U } \\
\text { Required phototherapy }\end{array}$ \\
\hline Niger $^{4}$ & $\begin{array}{l}\text { POM1G2 } \\
\text { Sickle cell anemia, prior transfusions } \\
\text { Antenatal antiglobulin test negative } \\
\text { Mother found to have anti- } U \text { after delivery }\end{array}$ & Neonate antiglobulin test negative \\
\hline United States ${ }^{5}$ & $\begin{array}{l}\text { P1G2 } \\
\text { Anti-U detected antenatally }\end{array}$ & $\begin{array}{l}\text { Neonate born at } 38 \text { weeks } \\
\text { Neonate had anti-U } \\
\text { No phototherapy required }\end{array}$ \\
\hline Nigeria $^{6}$ & $\begin{array}{l}\text { P3G4 } \\
\text { Anti-U titer increased from } 4 \text { to } 256 \text { at term } \\
\text { No fetal anemia detected antenatally }\end{array}$ & $\begin{array}{l}\text { Neonate born at } 38 \text { weeks } \\
\text { Neonate had anti-U } \\
\text { Required phototherapy }\end{array}$ \\
\hline Nigeria $^{2}$ & $\begin{array}{l}\text { P0M1G2 } \\
\text { Anti-U titer increased from } 4 \text { to } 4000 \text { at term } \\
\text { No fetal anemia detected antenatally }\end{array}$ & Required phototherapy \\
\hline Zimbabwe $^{2}$ & $\begin{array}{l}\text { POM1G2 } \\
\text { Anti-U detected } \\
\text { P1M1G3 } \\
\text { Anti-U titer increased from } 16 \text { to } 4000 \\
\text { P2M1G4 } \\
\text { Anti-U titer increased from } 512 \text { to } 2000\end{array}$ & $\begin{array}{l}\text { No phototherapy required } \\
\text { Neonate had anti-U } \\
\text { Required phototherapy } \\
\text { Neonate had anti-U } \\
\text { Required phototherapy }\end{array}$ \\
\hline Ghana $^{2}$ & $\begin{array}{l}\text { POM1G2 } \\
\text { Sickle cell trait } \\
\text { Anti-U titer } 8000 \\
\text { P1M1G3 } \\
\text { Sickle cell trait } \\
\text { Anti-U titer increased from } 1000 \text { to } 8000 \\
\text { Antenatal anemia detected: received four intrauterine } \\
\text { transfusions }\end{array}$ & $\begin{array}{l}\text { Growth-restricted neonate delivered at } 32 \text { weeks with } \\
\text { good Apgar score } \\
\text { Sickle cell negative } \\
\text { Neonate had anti-U } \\
\text { Required phototherapy } \\
\text { Neonate required transfusion: no suitable blood } \\
\text { available so transfused mother's prepared blood } \\
\text { (six transfusions over first } 18 \text { days of life) } \\
\text { Neonate received erythropoietin } \\
\text { Neonate born at } 32 \text { weeks due to fetal bradycardia } \\
\text { during fourth intrauterine transfusion } \\
\text { Neonate required phototherapy and an exchange } \\
\text { transfusion }\end{array}$ \\
\hline
\end{tabular}


level of more than $12 \mathrm{~g} / \mathrm{dL}$. A potential fetal advantage is that the RBCs may have a longer half-life and thus decrease the number of total intrauterine transfusions required.[9]

The management of pregnant women with rare antibodies in the absence of appropriately cross-matched blood products poses a challenge. The use of maternal donation for intrauterine transfusion offers an alternative for this potentially life-saving procedure. The use of maternal RBCs for intrauterine transfusions has been successfully described in cases with anti-K(u),[10] anti-Jsb,[11] and anti-Rh17.[12] The largest series of maternal blood donations during pregnancy was described by Gonsoulin and colleagues.[13] A total of 21 alloimmunized pregnant women donated a total of 77 units of blood for intrauterine transfusions. There was one fetal and two neonatal deaths. No maternal or fetal adverse events were attributed to the intrauterine transfusions in this series.

Another study compared the use of maternal blood versus donor blood for intrauterine transfusions. It was observed that the decline in fetal Hct was much slower in those fetuses receiving maternal blood. Furthermore, neonates who have received maternal blood required fewer postnatal transfusions.[14]

The maternal-fetal ABO-mismatched incompatibility is not deemed to present a significant risk for intrauterine transfusion because anti- $A$ and anti-B are not detected in a large population of fetuses during gestation and are absent or only weakly detectable in cord serum. However, ABO-mismatched transfusion should only be reserved for rare instances when antigen-compatible group O blood is unobtainable.[12]

Pregnant women who donate blood should receive iron supplementation. Erythropoietin (EPO) can also be considered to increase maternal Hct, if necessary. Case reports of EPO use later in pregnancy have reported no adverse events.[15]

Intrauterine fetal transfusion is not without risk.[16] These risks include perinatal death, emergency Cesarean section, infection, premature rupture of membranes, inadvertent arterial puncture, fetal tachycardia or bradycardia, or bleeding from the puncture site.

Overall survival after intrauterine transfusion is $89 \%$ but varies by center, experience, and presence of hydrops fetalis. Survival is worse if hydrops is present or severe anemia occurs before 20 weeks' gestation. Available data on long-term outcome of the child are necessary. The Lotus study[16] assessed the risk factors and incidence of neurodevelopmental impairment in children with HDN treated with intrauterine transfusion. They found that the neurodevelopmental outcome for children compared favorably with a group of high-risk, very-low-birthweight infants ( $10 \%$ vs. $18 \%$ ) but less favorably with a healthy control group ( $10 \%$ vs. $6 \%$ ). Fetal hydrops was found to be associated with increased mortality. Not much is known regarding the severity of fetal anemia and long-term neurodevelopmental outcome. In conclusion, autologous transfusion provides a safe option for intrauterine therapy in pregnancies complicated by rare alloantibodies.

\section{CONFLICT OF INTEREST}

The authors have disclosed no conflicts of interest. 


\section{REFERENCES}

1. Koelewijn JM, Vrijkotte TG, de Haas M, et al. Risk factors for the presence of non-rhesus (D) red blood cell antibodies in pregnancy. BJOG 2009;116:655.

2. Smith G, Knott P, Rissik J, et al. Anti-U and haemolytic disease of the fetus and newborn. Br J Obstet Gynaecol 1998;105:1318-21.

3. Novarethi MC, Jens E, Pagliarmi T, et al. Hemolytic disease of the newborn due to anti-U. Rev Hosp Clin Fac Med Sao Paulo 2003;58:320-3.

4. Ringressi A, Biagioni S, Mello G, et al. Anti-U alloimmunisation in a pregnant woman from Niger. Blood Transfus 2012;10:221-4.

5. Turner RJ, Holder WT, McCord DL. Isoimmunization with anti-U antibody. J Natl Med Assoc 1984;76:277-83.

6. Rana R, De Graaf F, Kumaranayakan P. Anti-U antibody in pregnancy: a rare antibody causing hemolytic disease. Acta Obstet Gynecol Scand 2011;90:555.

7. American College of Obstetricians and Gynecologists. ACOG Practice Bulletin No. 75: management of alloimmunization during pregnancy. Obstet Gynecol 2006;108:457-64.

8. Mari G, Deter RL, Carpenter RL, et al. Noninvasive diagnosis by Doppler ultrasonography of fetal anemia due to maternal red-cell alloimmunization. Collaborative Group for Doppler Assessment of the Blood Velocity in Anemic Fetuses. N Engl J Med 2000;342:9.

9. Vanderlinde ES, Heal JM, Blumberg N. Autologous transfusion. BMJ 2002;324:772.

10. Lydaki E, Nikoloudi I, Kaminopetros $P$, et al. Serial blood donations for intrauterine transfusions of severe hemolytic disease of the newborn with the use of recombinant erythropoietin in a pregnant woman alloimmunized with anti-Ku. Transfusion 2005;45:1791-5.

11. Al Riyami AZ, Al Salmani M, Al Hashami S, et al. Successful management of severe hemolytic disease of the fetus due to anti-Jsb using intrauterine transfusions with serial maternal blood donations: a case report and a review of the literature. Transfusion 2014;54:238-43.

12. Denomme GA, Ryan G, Seaward PG, et al. Maternal ABO-mismatched blood for intrauterine transfusion of severe hemolytic disease of the newborn due to anti-Rh17. Transfusion 2004;44:1357-60.

13. Gonsoulin WJ, Moise KJ, Milam JD, et al. Serial maternal blood donations for intrauterine transfusion. Obstet Gynecol 1990;75:158-62.

14. el-Azeem SA, Samuels $P$, Rose RL, et al. The effect of the source of transfused blood on the rate of consumption of transfused red blood cells in pregnancies affected by red blood cell alloimmunization. Am J Obstet Gynecol 1997;177:753.

15. Breyman C, Visca E, Huch R, et al. Efficacy and safety of intravenously administered iron sucrose with and without adjuvant recombinant human erythropoietin for the treatment of resistant iron-deficiency anaemia during pregnancy. Am J Obstet Gynecol 2001;184:662-7.

16. Verudin EP, Linderburg IT, Smits-Wintjens EH, et al. Long-term follow up after intra-uterine transfusion; the LOTUS study. BMC Pregnancy Childbirth 2010;10:77. 